\title{
M onitoring of ambient air quality in relation to traffic density in Bareilly City (U.P.), India
}

\section{R. K hanna, N. S. Nigam and R. B hutiani*}

Department of Zoology and Environmental Science, Gurukula Kangri University, Haridwar-249404 (Uttarakhand), INDIA

*Corresponding author. E-mail: rbhutiani@gmail.com

Received:O ctober 26, 2013; Revised received:D ecember 1, 2013; Accepted:D ecember 12, 2013

\begin{abstract}
An ambient air quality study was undertaken in Bareilly city, U.P., India during the year 2010 and 2011. The seasonal air quality data was obtained from ten monitoring sites across the city considering sampling site of Cantt as control site. The maximum $\left(713.06 \pm 55.64 \mu \mathrm{g} / \mathrm{m}^{3}\right)$ suspended particulate matter (SPM), sulphur dioxide $\left(\mathrm{SO}_{2}\right)$ $\left(80.08 \pm 4.77 \mu \mathrm{g} / \mathrm{m}^{3}\right)$ and nitrogen oxides $\left(\mathrm{NO}_{x}\right)\left(64.98 \pm 3.53 \mu \mathrm{g} / \mathrm{m}^{3}\right)$ level was found at Choupla during the winter 2011. Among the annual mean values of air pollutants were analyzed, SPM level was found to be above the National Ambient Air Quality Standards (NAAQS) $\left(200 \mu \mathrm{g} / \mathrm{m}^{3}\right)$ at all the polluted sites. $\mathrm{SO}_{2}$ and $\mathrm{NO}_{x}$ levels were below the threshold limits $\left(80 \mu \mathrm{g} / \mathrm{m}^{3}\right)$ as per NAAQS. The ambient air quality was correlated with the traffic density in the city. The pollution level was observed to be positively correlated with traffic density which is the major source of air pollution in the city. The ambient air quality at different monitoring sites was categorized into different pollution level on the basis of Oak ridge air quality index (ORAQI). Light to moderate air pollution conditions were present at different sites. Sampling site of Choupla $\left(\mathrm{S}_{\mathrm{VII}}\right)$ observe maximum ORAQI of 64.48 and 70.81 and falls under category of moderate pollution.
\end{abstract}

Keywords: Air quality, $\mathrm{NO}_{x}$, Oak ridge air quality Index, $\mathrm{SO}_{2}$, SPM, Traffic density

\section{INTRODUCTION}

The particulate and gaseous wastes of various human activities, e.g. burning of fossil fuels, transport, construction, mining etc. contributes various pollutants to the atmosphere. When the presence of these pollutants starts affecting the human beings and other biological systems the matter becomes a cause of concern (Jain and Saxena, 2002). With extensive industrialization and urbanization the particulate and gaseous waste generation and their disposal in atmosphere has attracted wide attention. Urban areas have in general been experiencing a higher concentration of air pollution due to extensive vehicular movements and other activities concentrated in comparatively smaller areas (Jain and Saxena, 2002).

Urbanization no doubt has a positive impact on income levels, employment and production economics, but it is accompanied with a number of problems such as shortage of housing, inadequate water supply, improper sanitation and waste disposal facilities, congestion, concentration of offices and business cum commercial places in the heart of the city, traffic problems and air, water and noise pollution (Smith et al., 1999; Mudgal et al., 2000).

There has been considerable decline in the air quality status in India during the past few decades on account of rapid industrialization, economic development and unecological planning. Rapidly growing cities, more traffic on roads, use of dirtier fuels, reliance on outdated industrial processes, growing energy consumption and lack of industrial zoning and environmental regulations are all contributing to the bad urban air and deteriorating public health. Mass-scale urban mobility with subsequent increase in urban population has led to the development of a transport system network to provide connections between different localities and cities. Emissions from heavily loaded and badly maintained automobiles contribute most to urban air pollution problem in India (Trivedi et al., 2003).

Since 1947, the population of the Bareilly city has increased alarming to its present population of 15,68 , 409 (Census, 2011). There has been approximately $27 \%$ increase in population during last decade. Large and small scale industries dot the entire outskirts of the city in all directions. The spurt in the industrial activity is phenomenal since 1970 . The inevitable population growth as a consequence during the last two decades is phenomenal requiring very intense and hectic construction activities. An outcome of these developments is the sudden increase in the vehicular traffic and the congestion thereof. In the present scenario of the problems faced by Bareilly city; urban transport is 


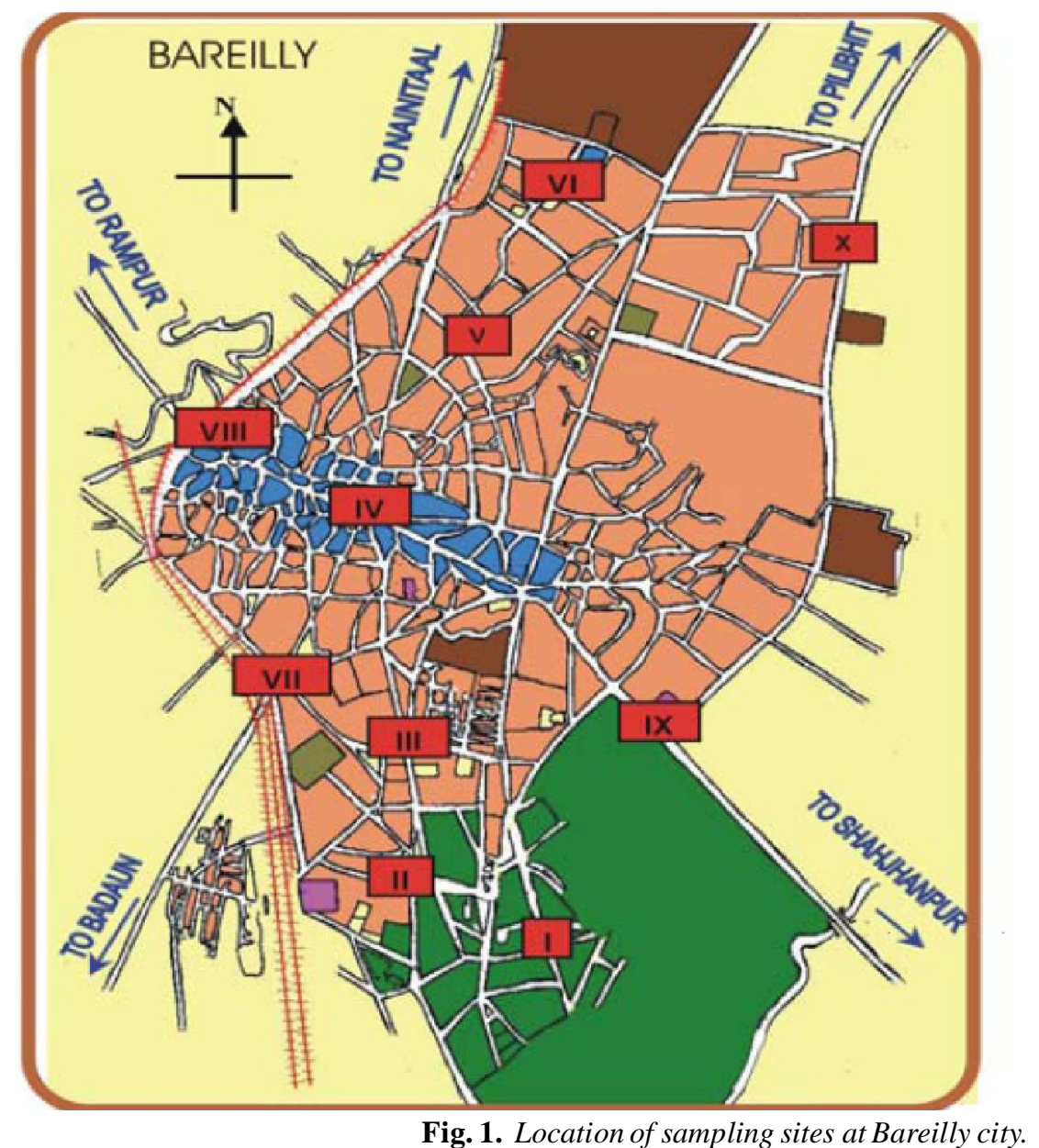

SAMPLING SITES

1- CANTT

(Control site)

II- RAILWAY STATION

III- $\mathrm{CHOWKI}$

CHOURAHA

IV- KUTUBKHANA

V- DARAMKANTA

VI- SHEEL CHOURAHA

VII- CHOUPLA

VIII- KILA

IX- PILIBHIT BY PASS

X-S. S. NAGAR

major source of pollution, which is further fueled by an inefficient and inadequate traffic transport system. The transport system in Bareilly city is under severe strain. The number of commuters traveling daily in different conveyances is much more than the normal capacity of the transport networks. There has been approximately $83 \%$ increase in the total registered vehicles during last seven years from 1999 to 2006. This might have resulted in deteriorating the quality of urban air surrounding the city. Therefore, the present study has been undertaken with the aim to determine the SPM, $\mathrm{SO}_{2}$ and $\mathrm{NO}_{\mathrm{x}}$ level in the ambient air at different road intersections during year 2010 and 2011 and its relation with traffic density of the city. The study also presents the impact of seasonal variation on the air quality of the city and to discuss possible reasons.

\section{MATERIALS AND METHODS}

Study area: The Bareilly district is located in the northern part of India and falls in the state of Uttar Pradesh. The city lies between the latitudes of $28^{\circ} 10^{\prime}$ and $28^{\circ} 54^{\prime} \mathrm{N}$ and longitudes of $78^{\circ} 58^{\prime}$ and $79^{\circ} 47^{\prime} \mathrm{E}$. The Northern boundary of the district is continuous with that of Nainital district, on the East lies the district of Pilibhit and on the South-East, Shahajahanpur district. On the South and South-West, it is bounded by the district of Badaun, the
Ramganga River forming the natural boundary between the two districts for about 19 miles. On the West lies the district Rampur. For the purpose of air quality monitoring, ten different sampling sites across the city were selected (Fig.1). The details of the sampling sites are given in table 1. The district of Bareilly goes through a cycle of four seasons during the year. The cool winters from December to February, followed by the warm summers which continue till about the middle of June, relief from the heat coming in the form of the South-West monsoons, ushering during the rainy season which lasts till the end of August. September, October and November constitute the post-monsoon season.

Sampling and analysis: The monitoring of air quality on the ten different road transactions was done in the above four seasons for three consecutive days in each season representing the particular season.

Air quality parameters were monitored by using high volume sampler (APM 410) following standard procedure laid down by Central Pollution Control Board. The concentrations of SPM, $\mathrm{SO}_{2}$ and $\mathrm{NO}_{\mathrm{x}}$ in the ambient air were determined according to Saxena (1990), West and Gaeke method (1956) and Jacob and Hochheiser's method (1958) respectively.

Oak ridge air quality index (ORAQI) was calculated 
according to Ghose et al. (2004).

$$
\text { ORAQI }=\left(9.61\left(\frac{C_{S P M(0)}}{C_{S P M(P)}}+\frac{C_{S_{2}(0)}}{C_{S_{2}(P)}}+\frac{C_{\mathrm{NO}_{x}(0)}}{C_{\mathrm{NO}_{X}(P)}}\right)\right) \times 1.37
$$

Where, $\mathrm{O}=$ observed value; $\mathrm{P}=$ primary standard (NAAQS)

The air quality of a location was determined on the basis of the Air Quality Index (AQI) values and divided into following categories-

Index value

$<25$

26-50

$51-75$

76- 100

$>100$

\section{RESULTS AND DISCUSSION}

Seasonal variation: Contour plots of $\mathrm{SPM}, \mathrm{SO}_{2}$ and $\mathrm{NO}_{x}$ as measured during summer, monsoon, post monsoon and winter season for two consecutive years 2010 and 2011 are shown in figs. 2 - 4 . When the ambient concentration of particulate and gaseous pollutants ( $\mathrm{SPM}, \mathrm{SO}_{2}$ and $\mathrm{NO}_{\mathrm{x}}$ ) was calculated, it was noted that the level of pollutants followed a particular trend having maximum concentration at sampling sites $\mathrm{S}_{\mathrm{II}}, \mathrm{S}_{\mathrm{VII}}$ and $\mathrm{S}_{\mathrm{VIII}}$ i.e. Railway station, Choupla and Kila during different seasons in year 2010 and 2011 and minimum at $S_{I}($ Cantt) which has been considered as control site. A significant seasonal variation $(\mathrm{p}<0.01)$ was seen during both the years at all the sites, where pollution level has increased in subsequent year.

The maximum $\mathrm{SPM}, \mathrm{SO}_{2}$ and $\mathrm{NO}_{\mathrm{x}}$ concentration was recorded at Choupla $\left(942.057 \mu \mathrm{g} / \mathrm{m}^{3}\right)$, Kila $\left(94.577 \mu \mathrm{g} / \mathrm{m}^{3}\right)$ and Railway station $\left(86.803 \mu \mathrm{g} / \mathrm{m}^{3}\right)$ respectively during the winter season of the year 2011. The minimum level of $\operatorname{SPM}\left(139.050 \mu \mathrm{g} / \mathrm{m}^{3}\right), \mathrm{SO}_{2}\left(6.933 \mu \mathrm{g} / \mathrm{m}^{3}\right)$ and $\mathrm{NO}_{\mathrm{x}}(6.347$ $\mu \mathrm{g} / \mathrm{m}^{3}$ ) were observed at Cantt during the monsoon Table 1. Details of sampling locations in Bareilly city.

\begin{tabular}{|c|c|c|c|c|}
\hline S. N. & Sampling site & Site No. & Land use & Remarks \\
\hline 1. & $\begin{array}{l}\text { Cantt } \\
\text { (Control site) }\end{array}$ & $\mathrm{S}_{\mathrm{I}}$ & Restricted zone & Indian Army base, dense vegetation \\
\hline 2. & Railway Station & $\mathrm{S}_{\mathrm{II}}$ & Commercial and Residential & $\begin{array}{l}\text { Railway station, high density of } \\
\text { population }\end{array}$ \\
\hline 3. & Chowki Chouraha & $\mathrm{S}_{\text {III }}$ & Commercial & Business complexes, Govt. offices \\
\hline 4. & Kutubkhana & $\mathrm{S}_{\text {IV }}$ & Commercial & Market place, very congested area \\
\hline 5. & Daramkanta & $\mathrm{S}_{\mathrm{V}}$ & Commercial and Residential & Densely populated area \\
\hline 6. & Sheel Chouraha & $\mathrm{S}_{\mathrm{VI}}$ & $\begin{array}{l}\text { Residential and Slightly } \\
\text { Commercial }\end{array}$ & Hospitals, open spaces \\
\hline 7. & Choupla & $\mathrm{S}_{\text {VII }}$ & Commercial & NH No. 24 , traffic intersection, \\
\hline 8. & Kila & $\mathrm{S}_{\text {VIII }}$ & Commercial & $\begin{array}{l}\text { NH No. } 24 \text {, traffic intersection, railway } \\
\text { track and over bridge passing by }\end{array}$ \\
\hline 9. & Pilibhit by pass & $\mathrm{S}_{\text {IX }}$ & Commercial & $\begin{array}{l}\text { Satellite bus stand, National Highway } \\
\text { No. } 24\end{array}$ \\
\hline 10. & S.S. Nagar & $\mathrm{S}_{\mathrm{X}}$ & Residential & Open street, vegetation \\
\hline
\end{tabular}
and $\mathrm{NO}_{\mathrm{x}}$ was seen during winter and lowest during concentration of SPM $\left(639.386 \pm 43.499 \mu \mathrm{g} / \mathrm{m}^{3}\right.$ and season of the year 2010 .

Air pollution status in any air-shed is governed by its meteorological conditions which play a crucial role. Different studies indicate that the particulate and gaseous pollutants concentration in the ambient air is also affected by various meteorological factors such as wind speed, wind direction, solar radiation, relative humidity etc. as well as the source conditions (Monn et al., 1995; Prendez et al., 1995). Factors such as road dust, high traffic density, poorly maintained heavy vehicles, increasing 23 wheelers, prolonged periods at the traffic signals, seems to deteriorates the air quality of the city.

In the present study, highest concentration of SPM, $\mathrm{SO}_{2}$ monsoon season. This may be because of the high fuel usage in winter which has further added to the pollution load. Also during winter months, the pollutants emitted from various anthropogenic and natural sources are trapped below the boundary layer due to frequent temperature inversions, while during the summer months this polluted air mixes with the free tropospheric air causing dilution of the pollutants.

A nnual distribution of pollutant concentration: The annual mean values of air pollutants during the year 2010 and 2011 are given in table 2 . The maximum annual mean $\left.713.061 \pm 55.646 \mu \mathrm{g} / \mathrm{m}^{3}\right)$ and $\mathrm{SO}_{2}\left(81.190 \pm 4.810 \mu \mathrm{g} / \mathrm{m}^{3}\right.$ and $\left.82.119 \pm 4.439 \mu \mathrm{g} / \mathrm{m}^{3}\right)$ during 2010 and 2011 was observed at Choupla and Kila. The annual mean value of $\mathrm{NO}_{\mathrm{x}}$ was highest at Railway station $\left(67.105 \pm 5.201 \mu \mathrm{g} / \mathrm{m}^{3}\right)$ in 2010 and at Kila $\left(71.450 \pm 2.269 \mu \mathrm{g} / \mathrm{m}^{3}\right)$ in 2011 . On annual comparison, it was observed that air pollutants level has increased in the year 2011 than the previous year. The annual average values of $\mathrm{SPM}, \mathrm{SO}_{2}$ and $\mathrm{NO}_{\mathrm{x}}$ at control site were SPM $\left(161.769 \pm 8.012 \mu \mathrm{g} / \mathrm{m}^{3}\right.$ and $176.021 \pm 9.618$ $\left.\mu \mathrm{g} / \mathrm{m}^{3}\right), \mathrm{SO}_{2}\left(13.727 \pm 1.763 \mu \mathrm{g} / \mathrm{m}^{3}\right.$ and $\left.16.843 \pm 2.724 \mu \mathrm{g} / \mathrm{m}^{3}\right)$ and $\mathrm{NO}_{\mathrm{x}}\left(15.393 \pm 1.666 \mu \mathrm{g} / \mathrm{m}^{3}\right.$ and $\left.16.648 \pm 1.807 \mu \mathrm{g} / \mathrm{m}^{3}\right)$ 
Table 2. Annual average values of suspended particulate matter, sulphur dioxide and nitrogen oxides at different sampling sites in Bareilly city during the year 2010 and 2011.

\begin{tabular}{|c|c|c|c|c|c|c|c|}
\hline \multirow[t]{2}{*}{ Sampling site } & & \multicolumn{2}{|c|}{$\mathrm{SPM}\left(\mu \mathrm{g} / \mathrm{m}^{3}\right)$} & \multicolumn{2}{|c|}{$\mathrm{SO}_{2}\left(\mu \mathrm{g} / \mathrm{m}^{3}\right)$} & \multicolumn{2}{|c|}{$\mathrm{NO}_{\mathrm{x}}\left(\mu \mathrm{g} / \mathrm{m}^{3}\right)$} \\
\hline & & 2010 & 2011 & 2010 & 2011 & 2010 & 2011 \\
\hline Cantt (Control site) & $\mathrm{S}_{\mathrm{I}}$ & $161.76 \pm 8.01$ & $176.02 \pm 9.61$ & $13.72 \pm 1.76$ & $16.84 \pm 2.72$ & $15.39 \pm 1.66$ & $16.64 \pm 1.80$ \\
\hline Railway station & $\mathrm{S}_{\text {II }}$ & $448.43 \pm 45.18$ & $462.18 \pm 49.72$ & $59.99 \pm 5.88$ & $65.70 \pm 4.99$ & $67.10 \pm 5.20$ & $70.51 \pm 5.00$ \\
\hline Chowki Chouraha & $\mathrm{S}_{\text {III }}$ & $396.18 \pm 42.43$ & $420.95 \pm 40.72$ & $60.82 \pm 4.86$ & $63.44 \pm 6.38$ & $65.13 \pm 3.35$ & $69.89 \pm 3.31$ \\
\hline Kutubkhana & $\mathrm{S}_{\mathrm{IV}}$ & $425.34 \pm 23.67$ & $426.57 \pm 22.53$ & $43.81 \pm 5.07$ & $48.21 \pm 6.25$ & $30.15 \pm 1.60$ & $34.08 \pm 1.67$ \\
\hline Daramkanta & $\mathrm{S}_{\mathrm{V}}$ & $415.59 \pm 28.71$ & $430.49 \pm 28.52$ & $35.02 \pm 4.99$ & $30.72 \pm 4.41$ & $42.60 \pm 2.69$ & $46.28 \pm 3.12$ \\
\hline Sheel Chouraha & $\mathrm{S}_{\mathrm{VI}}$ & $317.41 \pm 38.12$ & $343.68 \pm 38.24$ & $31.75 \pm 5.08$ & $39.43 \pm 4.88$ & $41.36 \pm 3.61$ & $45.74 \pm 3.85$ \\
\hline Choupla & $\mathrm{S}_{\text {VII }}$ & $639.38 \pm 43.49$ & $713.06 \pm 55.64$ & $74.74 \pm 4.21$ & $80.08 \pm 4.77$ & $61.29 \pm 3.56$ & $64.98 \pm 3.53$ \\
\hline Kila & $\mathrm{S}_{\text {VIII }}$ & $615.13 \pm 39.86$ & $676.57 \pm 36.74$ & $81.19 \pm 4.81$ & $82.11 \pm 4.43$ & $66.51 \pm 2.72$ & $71.45 \pm 2.26$ \\
\hline Pilibhit by pass & $\mathrm{S}_{\mathrm{IX}}$ & $528.08 \pm 54.76$ & $542.84 \pm 57.57$ & $62.41 \pm 5.81$ & $70.25 \pm 7.37$ & $35.53 \pm 2.70$ & $40.12 \pm 2.86$ \\
\hline S.S. Nagar & $\mathrm{S}_{\mathrm{X}}$ & $363.52 \pm 26.10$ & $404.30 \pm 29.91$ & $54.61 \pm 5.36$ & $48.52 \pm 6.16$ & $27.84 \pm 1.85$ & $32.03 \pm 2.58$ \\
\hline
\end{tabular}

Values are represented as mean $\pm \mathrm{SE}$ of three replicates.

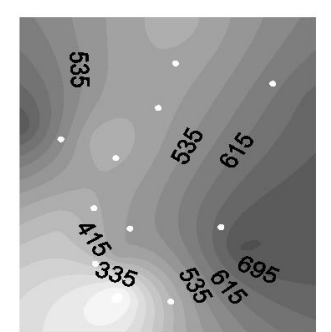

Summer-2010

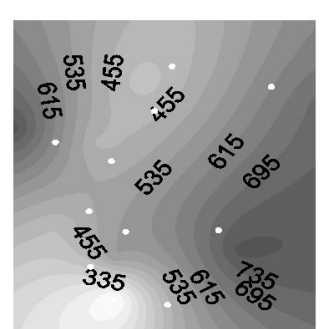

Summer-2011

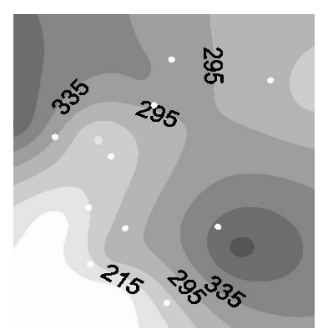

M onsoon-2010

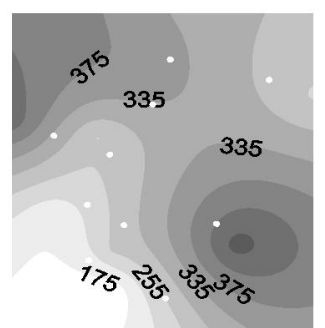

M onsoon-2011

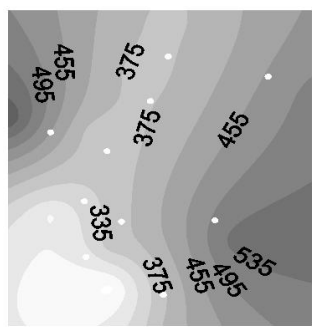

Postmonsoon-2010

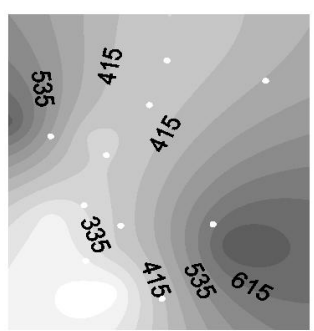

Postmonsoon-2011

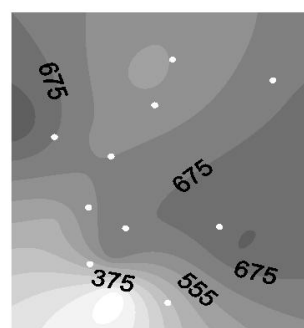

Winter-2010 Scale $\mathrm{NO}_{x}\left(\mu \mathrm{g} / \mathrm{m}^{3}\right)$

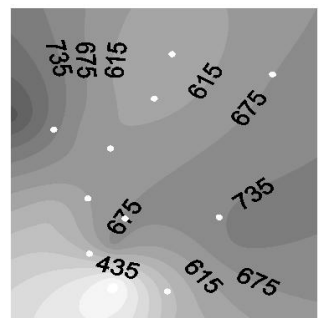

Winter-2011 Scale $\mathrm{NO}_{x}\left(\mu \mathrm{g} / \mathrm{m}^{3}\right)$

Fig. 2. Concentration of SPM in Bareilly city during different seasons of the year 2010 and 2011.

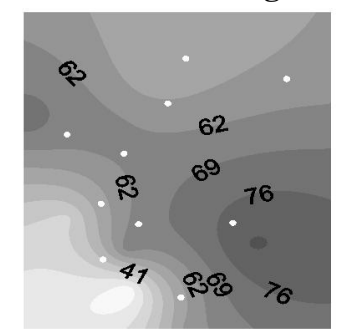

Summer -2010

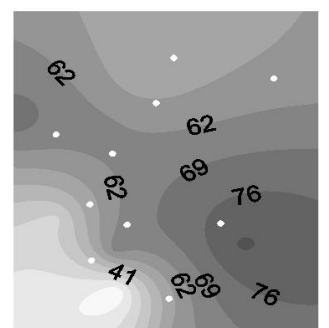

Summer-2011

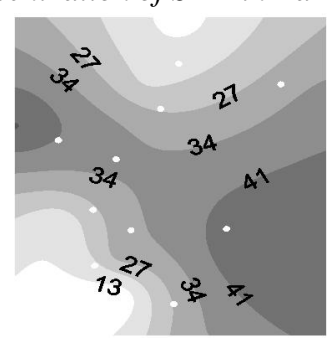

M onsoon-2010

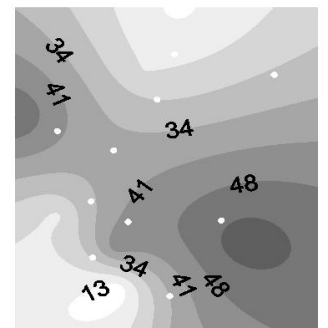

M onsoon-2011

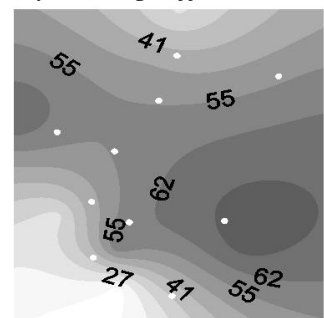

Postmonsoon-2010

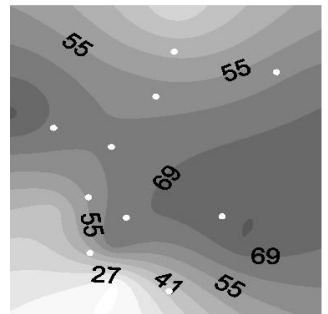

Postmonsoon-2011

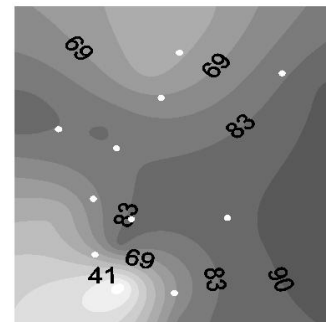

Winter-2010 Scale $\mathrm{NO}_{x}\left(\mu \mathrm{g} / \mathrm{m}^{3}\right)$

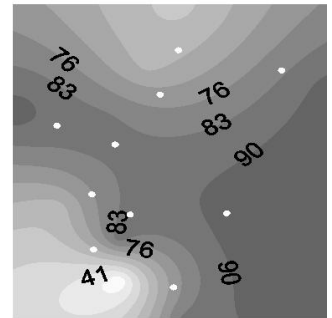

Winter-2011 Scale $\mathrm{NO}_{\mathrm{x}}\left(\mu \mathrm{g} / \mathrm{m}^{3}\right)$

Fig. 3. Concentration of $\mathrm{SO}_{2}$ in Bareilly city during different seasons of the year 2010 and 2011. 


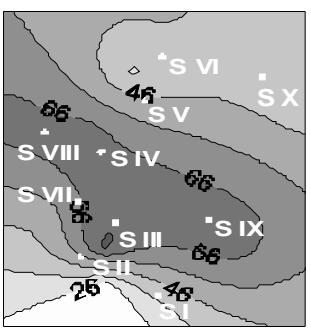

Summer-2010

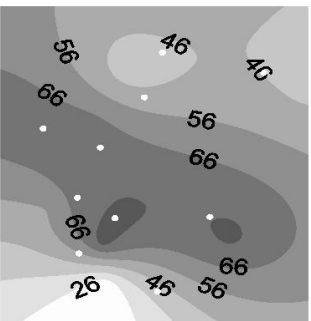

Summer-2011

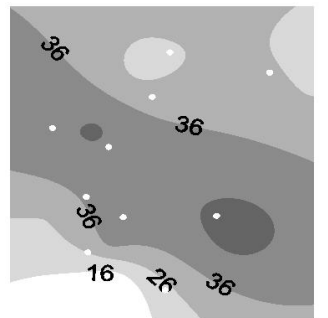

M onsoon-2010

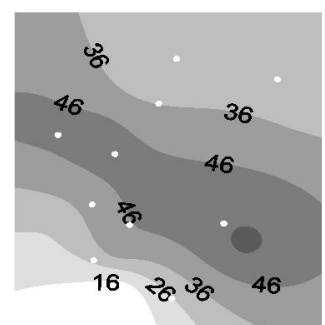

M onsoon-2011

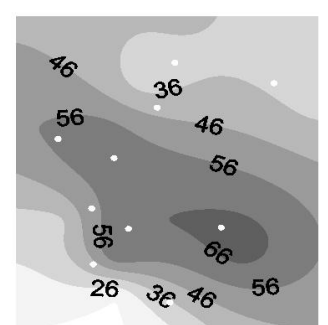

Postmonsoon-2010

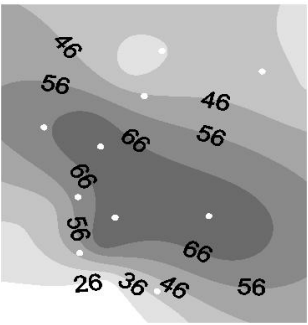

Postmonsoon-2011

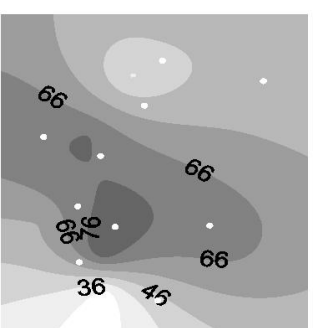

W inter-2010 Scale $\mathrm{NO}_{\mathrm{x}}\left(\mu \mathrm{g} / \mathrm{m}^{3}\right)$

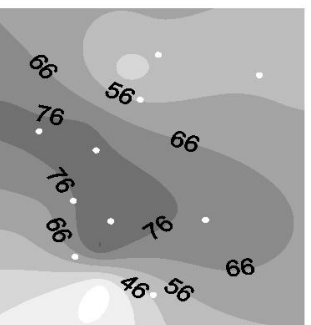

Winter-2011 Scale NO $\left(\mu \mathrm{g} / \mathrm{m}^{3}\right)$

Fig. 4. Concentration of $\mathrm{NO}_{x}$ in Bareilily city during different seasons of the year 2010 and 2011.

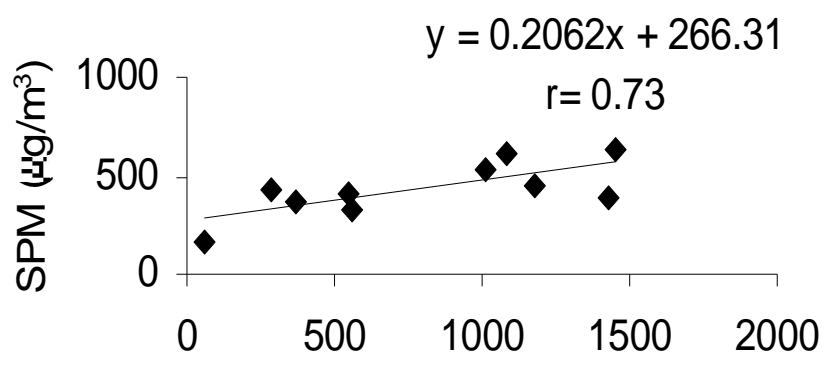

Traffic Density (Vehicles $/ \mathrm{hr}$ )

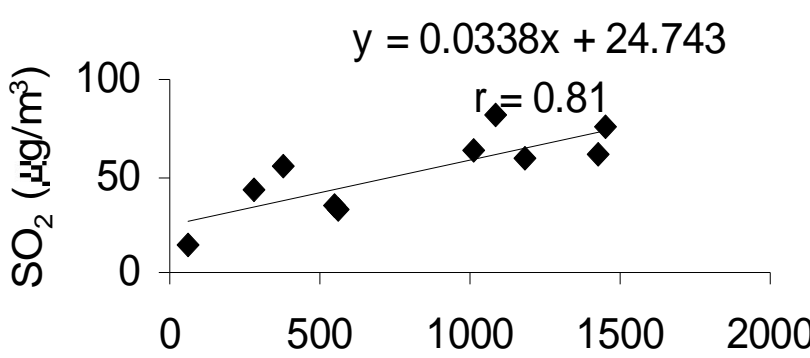

Traffic Density (Vehicles/hr)

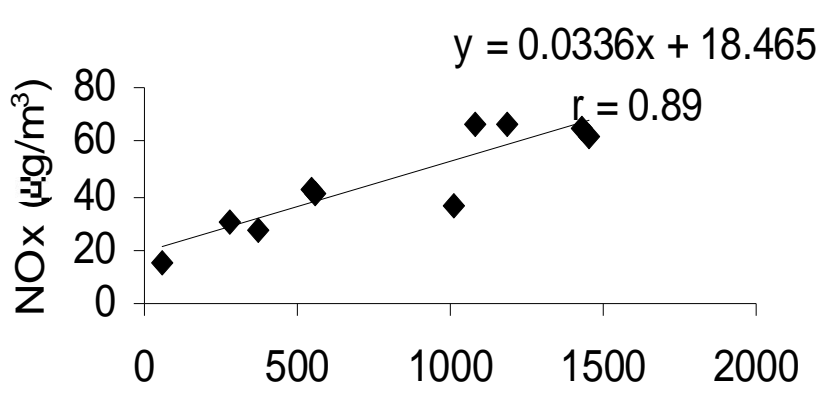

Traffic Density (Vehicles/hr)

Fig. 5. Correlation between $\mathrm{SPM}, \mathrm{SO}_{2}$ and $\mathrm{NO}_{x}$ and traffic density in Bareilly city. during year 2010 and 2011 respectively.

When the annual mean values of air pollutants were analyzed, it was observed that SPM level at all the polluted sampling sites was above the National Ambient Air Quality Standard-NAAQS $\left(200 \mu \mathrm{g} / \mathrm{m}^{3}\right)$. The SPMlevel at control site was below the permissible limits. Although the gaseous pollutants at all the sites were noted below the threshold limits $\left(80 \mu \mathrm{g} / \mathrm{m}^{3}\right)$ as per NAAQS, the $\mathrm{SO}_{2}$ level at Choupla and Kila were found on the edge of permissible limits in 2011.

Relation between traffic density and pollutant concentration: The vehicular density, the type of vehicles plying on the road, the road conditions etc. are some of major factors affecting ambient pollutant concentration on the roadside. Hence, in the present study, the vehicular traffic density during the air monitoring has also been estimated. When the primary pollutants level at different sites was compared with traffic density, positive correlation was found indicating that the traffic population is the main culprit for urban pollution (Fig. 5). The correlation coefficient for vehicles plying per hour at road intersections and SPM ranges 0.55 to 0.90 in different seasons. The gaseous pollutants $\left(\mathrm{SO}_{2}\right.$ and $\left.\mathrm{NO}_{\mathbf{x}}\right)$ exhibit the correlation coefficient ranging 0.83 to 0.91 with traffic volume.

The observed high level of particulate and gaseous pollutants can be explained by high traffic density in Bareilly city. This happened because the numbers of motorized vehicles have been increased from 1,23,342 in the year 1999 to 2,25,457 in the year 2011 showing 82.80 $\%$ increase. This is accompanied by slow-speed movement, frequent deceleration and acceleration of vehicles, as well as undesirable and unnecessary idling time of vehicles on the roads. Slower speed $(<30 \mathrm{~km} / \mathrm{hr})$ 
with increased phases of acceleration and deceleration results in significantly large emission factors than do higher cruising speeds (Kandilkar and Ramachandran, 2000). Apart from the emission factors of vehicles, the suspended particulate matter concentration on the street level would be mainly affected by the mechanical turbulence created by the moving vehicles and wind and the thermal turbulence produced by the hot vehicle exhaust gas (Lam et al., 1998). A significant amount of road dust present on the road and also on the road shoulder could be another important source of SPM as it is kept in suspension by vehicular movements (Gadgil and Jadhav, 2004). Samanta et al. (1998) stated that the $\mathrm{SO}_{2}$ and $\mathrm{NO}_{x}$ in the presence of SPM can create increasing environmental problems.

Oak ridge air quality index (ORAQI): In the present study, Oak ridge air quality index has been used for the relative ranking of overall air quality status at different locations of Bareilly city. The calculated values were compared with the relative scale of ORAQI. Table 3 represents overview of Bareilly air quality status on indices basis at different locations of the city in descriptive categories viz. clean air, light air pollution, moderate air pollution, heavy air pollution and severe air pollution. The annual mean values of ORAQI indicate that the sampling sites of $\mathrm{S}_{\mathrm{II}}$ (Railway station), $\mathrm{S}_{\mathrm{VI}}$ (Choupla), $\mathrm{S}_{\mathrm{VIII}}$ (Kila) and $\mathrm{S}_{\mathrm{IX}}$ (Pilibhit by pass) exhibits the moderate air pollution whereas $S_{\text {III }}$ (Chowki Chouraha), $S_{\mathrm{IV}}$ (Kutubkhana), $S_{\mathrm{V}}$ (Daramkanta), $\mathrm{S}_{\mathrm{VI}}$ (Sheel Chouraha) and $S_{X}$ (S.S. Nagar) bears the light air pollution. Clean air condition was found only at $S_{I}$ i.e. Cantt area. Sampling sites of $\mathrm{S}_{\mathrm{VII}}$ and $\mathrm{S}_{\mathrm{VIII}}$ has reached the heavy air pollution category during winters. Air pollution indices are useful as they indicate day to day change in air quality status. Air pollution index (API)/ Air quality index (AQI) is a scheme that transform the weighted values of individual air pollutant species (one or more) in a single number (Reddy et al., 2004). Therefore, Oak Ridge Air Quality Index (ORAQI), and Air pollution index (API)/ Air quality index (AQI) can be used as a tool to report overall environmental status.

\section{Conclusion}

The status of air pollution at different traffic intersections in Bareilly city was found to be in the category of light and moderate air pollution as determined by ORAQI. Choupla and Kila were identified as the highest polluted sites in comparison to all other sites in respect of SPM, $\mathrm{NO}_{\mathrm{x}}$ and $\mathrm{SO}_{2}$. A significant $(\mathrm{p}<0.01)$ seasonal variation was found in the pollutant levels experiencing maximum pollution during winter season and minimum in monsoon season. Since all the monitoring sites were located on the major roads, the local traffic conditions have affected directly the measured pollution levels which has also been reflected in the present study having a positive correlation between pollutants concentration and traffic volume at different monitoring sites.

\section{REFERENCES}

Census, (2011). Primary census abstract. Retrieved October 22, 2013 from http://www.censusindia.gov.in/towns/ town.aspx

Gadgil, A.S. and Jadhav, R.S. (2004). Street-level concentrations of suspended particulate matter (SPM), nitrogen dioxide $\left(\mathrm{NO}_{2}\right)$ and sulphur dioxide $\left(\mathrm{SO}_{2}\right)$ in Pune city. J r. Environ. Sci. \& Engg., 46(2): 143-150.

Ghose, M.K., Paul, R. and Banerjee, S.K. (2004). Assessment of the impacts of vehicular pollution on urban air quality. $\mathrm{r}$. Environ. Sci. \& Engg., 46(1): 33-40.

Jacob, M. B. and Hochheiser (1958). Continuous sampling and ultramicro determination of nitrogen dioxide in air. Anal. Chem., 30(3): 426-428.

Jain, M. K. and Saxena, N.C. (2002). Air quality assessment along Dhanbad- Jharia road. Environ. M onit. \& Assess., 79: 239-250.

Kandilkar, M. and Ramachandran, G. (2000). The causes and consequences of particulate air pollution in urban India: A synthesis. Annual Review of Energy \& Environment, 25: 629- 684.

Lam, G.C.K., Leung, D.Y.C., Niewiadomski, M., Pang, S.W., Lee, A.W.F. and Louie, P.K.K. (1998). Street level concentration of nitrogen dioxide and suspended particulate matter in HongKong. A tm. Env., 33: 1-11.

Monn, C.H., Braendli, O., Schaeppi, G., Schindler, C.H., Ackermann, U., Leuenberger, P.H. and Sapaldia, T. (1995). Particulate matter $<10 \mu \mathrm{m}$ in urban, rural and Alpine air in Switzerland. Atm. Env., 29: 2565- 2573.

Mudgal, R., Sharma, B., Upadhyay, R. and Taneja, A. (2000). Seasonal variation of ambient air quality at selected sites in Agra city. Indian J r. Radio \& Space Physics, 29(6): $127-$ 133.

Prendez, M.M., Egido, M., Tomas, C., Seco, J., Calvo, A. and Romero, H. (1995). Correlation between solar radiation and total suspended matter in Santiage, Chile. Atm. Env., 29: 1543- 1551.

Reddy, M. K., Ramarao, K. G. and Rao, I. R. (2004). Air quality status of Visakhapatnam (India) - Indices Basis. Environ. M onit. \& Assess., 95:1- 12 .

Samanta, G., Chattopadhyay, G., Mandal, B.K., Roy Chowdhury, T., Chowdhury, P.P., Chanda, C.R., Banerjee, P., Lodh, D., Das, D. and Chakborti, D. (1998). Air pollution in Calcutta during winter- A three year study. Current Sci., 75 (2): 123- 138.

Saxena, M. M. (1990). In: Environmental analysis: Water, soil and air. Agro-Botanical Publisher, Bikaner, India.

Smith, K. R., Corvalan, C. F. and Kjellstrom, T. (1999). How much global ill health is attributable to environmental factors? E pidemiology, 10(5): 573-584.

Trivedi, S.; Agarwal, M. and Rajput, M. (2003). Trends in sulphur dioxide and nitrogen dioxide concentrations in and around Varanasi over the period 1989-2001. Indian J r. Air Polln. Cont., 3(2): 54-62

West, P. D.and Gaeke, G. C. (1956). Fixation of sulphur dioxide as sulfitomercurate (II) and subsequent colorimetric estimation. Anal. Chem., 28: 1816- 1819. 